\title{
Blockade of Endogenous Neurotrophic Factors Prevents the Androgenic Rescue of Rat Spinal Motoneurons
}

\author{
Jun Xu, ${ }^{1}$ Karen M. Gingras, ${ }^{1}$ Lynn Bengston, ${ }^{1}$ Annalise Di Marco, ${ }^{2}$ and Nancy G. Forger ${ }^{1}$ \\ ${ }^{1}$ Center for Neuroendocrine Studies and Department of Psychology, University of Massachusetts, Amherst, \\ Massachusetts 01003, and 2Instituto di Ricerche di Biologia Molecolare P. Angeletti (IRBM), 00040 Pomezia, Rome, Italy
}

\begin{abstract}
Target-derived neurotrophic factors are assumed to regulate motoneuron cell death during development but remain unspecified. Motoneuron cell death in the spinal nucleus of the bulbocavernosus (SNB) of rats extends postnatally and is controlled by androgens. We exploited these features of the SNB system to identify endogenously produced trophic factors regulating motoneuron survival. Newborn female rat pups were treated with the androgen, testosterone propionate, or the oil vehicle alone. In addition, females received trophic factor antagonists delivered either into the perineum (the site of SNB target muscles) or systemically. Fusion molecules that bind and sequester the neurotrophins (trkA-lgG, trkB-lgG, and trkC-lgG) were used to block activation of neurotrophin receptors, and AADH-CNTF
\end{abstract}

Roughly half of all motoneurons initially produced in developing vertebrates die during a period of naturally occurring cell death, and trophic factors produced by target muscles are thought to be critical regulators of motoneuron survival (Hollyday and Hamburger, 1976; Oppenheim, 1991). More than a dozen trophic factors have been shown to enhance the survival of motoneurons when added in vitro or in vivo (for review, see Oppenheim, 1996; Mitsumoto and Tsuzaka, 1999). However, the administration of exogenous trophic factors may not mimic normal developmental events, and the endogenously produced factors that regulate naturally occurring motoneuron cell death remain unknown. One obstacle in identifying endogenous motoneuron trophic factors is that the period of cell death for most mammalian motoneurons is exclusively prenatal (Lance-Jones, 1982; Harris and McCaig, 1984; Oppenheim, 1986), thus rendering the manipulation of motoneuron-target interactions difficult.

Motoneurons in the spinal nucleus of the bulbocavernosus (SNB) are exceptional in that naturally occurring cell death extends postnatally and is regulated by androgens. SNB motoneurons reside in the lower lumbar spinal cord and innervate striated perineal muscles, including the bulbocavernosus (BC), levator ani (LA), and external anal sphincter (Schroder, 1980). Although SNB motoneurons and their target muscles develop in both sexes prenatally, the postnatal survival of this system is dependent on androgens. As a result, the BC/LA muscles and most SNB motoneurons normally degenerate in females (Cihak et al., 1970; Nordeen et al., 1985; Breedlove, 1986) but

Received Dec. 22, 2000; revised March 28, 2001; accepted March 29, 2001.

This work was supported by National Institutes of Health Grants HD33044 and HD01188 and the Whitehall Foundation.

Correspondence should be addressed to Dr. Nancy G. Forger, Department of Psychology, University of Massachusetts, Amherst, MA 01003. E-mail: nforger@psych.umass.edu.

Copyright (C) 2001 Society for Neuroscience $0270-6474 / 01 / 214366-07 \$ 15.00 / 0$ was used to antagonize signaling through the ciliary neurotrophic factor receptor- $\alpha$ (CNTFR $\alpha$ ). An acute blockade of trkB, $\operatorname{trkC}$, or CNTFR $\alpha$ prevented the androgenic sparing of SNB motoneurons when antagonists were delivered to the perineum. Trophic factor antagonists did not significantly reduce SNB motoneuron number when higher doses were injected systemically. These findings demonstrate a requirement for specific, endogenously produced trophic factors in the androgenic rescue of SNB motoneurons and further suggest that trophic factor interactions at the perineum play a crucial role in masculinization of this neural system.

Key words: motoneuron; cell death; androgen; neurotrophin; ciliary neurotrophic factor; trk receptor

can be permanently spared in females treated with testosterone during the perinatal cell death period (Breedlove and Arnold, 1983; Nordeen et al., 1985). Androgens apparently act directly at the $\mathrm{BC} / \mathrm{LA}$ muscles to prevent their degeneration, with the sparing of SNB cells resulting as an indirect consequence of hormone action at the muscles (Fishman et al., 1990; Freeman et al., 1997; Jordan et al., 1997). These observations suggest that the death of SNB motoneurons in females results from a loss of trophic factor support from their (degenerating) target muscles.

The postnatal occurrence of cell death and the easy accessibility of the perineal target muscles make the SNB an ideal system for studying trophic factor interactions regulating motoneuron survival. We previously implicated ciliary neurotrophic factor (CNTF) in the control of SNB motoneuron survival on the basis of the administration of exogenous CNTF and examination of the SNB system in mice lacking the CNTF receptor- $\alpha$ (CNTFR $\alpha$ ) (Forger et al., 1993; Bengston et al., 1996; Forger et al., 1997). However, it is likely that multiple trophic factors collaborate to regulate motoneuron survival (Mitsumoto et al., 1994; Ip and Yancopoulos, 1996). Several members of the neurotrophin family of neurotrophic factors, including brain-derived neurotrophic factor (BDNF), neurotrophin-3 (NT-3), and neurotrophin-4/5 (NT4/5) have potent survival-promoting effects on spinal motoneurons when administered exogenously (for review, see Oppenheim, 1996; Mitsumoto and Tsuzaka, 1999). In the present study, we tested the requirement for endogenous trophic factors in SNB motoneuron survival by treating androgenized female rat pups with agents designed to block the activation of neurotrophin or CNTF receptors. We found that the acute, localized blockade of single trophic factor receptors can prevent the androgenic rescue of SNB motoneurons. 


\section{MATERIALS AND METHODS}

Trophic factor antagonists. The neurotrophins signal primarily through the trk family of cell surface tyrosine kinase receptors: trkA is the high-affinity receptor for NGF, trkB binds both BDNF and NT-4, and trkC is the primary receptor for NT-3 (for review, see Bothwell, 1995). In the present study, the activity of endogenous neurotrophins was blocked using trk-IgGs, which are fusion proteins constructed from the extracellular domains of trkA, trkB, or trkC linked to the Fc tail of human IgG (Shelton et al., 1995). Trk-IgGs bind the respective neurotrophins with normal affinity and specificity and function effectively as competitive antagonists of the trk receptors in binding of endogenous ligand in vitro (Shelton et al., 1995; Lowenstein and Arsenault, 1996; Shimada et al., 1998) or in vivo (McMahon et al., 1995; Cabelli et al., 1997; Bennett et al., 1998). TrkA-IgG, trkB-IgG, and trkC-IgG were kindly provided by Stanley Wiegand (Regeneron Pharmaceuticals, Tarrytown, NY).

A competitive antagonist of $\mathrm{CNTF}$ receptor activation, AADHCNTF, was generously provided by Ralph Laufer (Instituto di Ricerche di Biologia Molecolare P. Angeletti, Rome, Italy). AADH-CNTF was created by introducing four amino acid substitutions into the native CNTF molecule. This CNTF variant binds the ligand-binding subunit of the CNTF receptor, CNTFR $\alpha$, with high affinity but, when bound, prevents CNTFR $\alpha$ from recruiting the signal-transducing subunit, leukemia inhibitory factor receptor $\beta$ (Di Marco et al., 1996). In vivo, AADH-CNTF antagonizes CNTF action in the brain (Meazza et al., 1997) and in adult spinal motoneurons (MacLennan et al., 2000).

Animals and treatments. Animals used in this study were neonatal female Sprague Dawley rats born in our laboratory to timed-pregnant dams (Taconic, Germantown, NY). Androgen treatments consisted of $125 \mu \mathrm{g}$ of testosterone propionate (TP; Sigma, St. Louis, MO) dissolved in $50 \mu \mathrm{l}$ of sesame oil, delivered subcutaneously on postnatal days 1 and 2 (P1 and P2). Control females received $50 \mu \mathrm{l}$ of the oil vehicle alone.

Trophic factor antagonists were dissolved in PBS and injected into the perineum or systemically on $\mathrm{P} 1, \mathrm{P} 2$, and $\mathrm{P} 3$. For perineal injections, pups were anesthetized on ice, and a Hamilton syringe was used to deliver 5 $\mu \mathrm{l}$ of total volume into the region midway between the anus and clitoris (Forger et al., 1993, 1995). For systemic administration, antagonists and control solutions were delivered in a volume of $50 \mu \mathrm{l}$, subcutaneously at the nape of the neck. Antagonists included AADH-CNTF and trk-IgG fusion proteins (trkA-IgG, trkB-IgG, and trkC-IgG) at the doses indicated below. Doses were chosen on the basis of previously published work and on the results of a pilot study in our laboratory. Pups injected with PBS alone or the Fc portion of human IgG (Chemicon, Temecula, CA) alone served as controls for antagonist treatments.

On P16, animals were weighed, overdosed with chlorapent $(0.25 \mathrm{M}$ chloral hydrate, $45 \mathrm{~mm}$ pentobarbital), and perfused with saline followed by $10 \%$ buffered formalin. The perineal region and the lumbosacral spinal cords were removed from all animals and post-fixed in formalin for at least 1 week. Spinal cords were immersed in Bouin's solution for $3 \mathrm{~d}$, embedded in paraffin, sectioned in the coronal plane at $15 \mu \mathrm{m}$, mounted onto slides, and stained with thionin.

A preliminary analysis, based on gross dissections and on the qualitative examination of tissue sections through the perineum, was performed on the perineal muscles of a subset of the animals in this study (E. Pedapati and N.G. Forger, unpublished observations). BC/LA muscles could not be identified in any oil-treated females. In contrast, both the $\mathrm{BC}$ and LA muscles were present in all TP-treated females examined. Thus, the $\mathrm{BC} / \mathrm{LA}$ muscles were at least partially rescued in all androgenized females, regardless of whether trophic factor antagonists or control solutions were administered to the perineum.

Motoneuron number and size. Counts of motoneurons were performed as described previously (Forger et al., 1993, 1995; Bengston et al., 1996). For comparison with the SNB, counts of the retrodorsolateral nucleus (RDLN) were also performed. RDLN motoneurons reside in the lateral horn at the same level of the spinal cord as the SNB and innervate intrinsic muscles of the foot (Nicolopoulos-Stournaras and Iles, 1983). Motoneuron survival in the RDLN is neither sexually dimorphic nor androgen-dependent (Jordan et al., 1982). Motoneurons in the SNB were counted bilaterally in alternate sections, whereas RDLN motoneurons were counted unilaterally in alternate sections. A motoneuron was counted only if the nucleus was clearly visible. Raw cell counts were corrected for nucleus size and for sampling ratio by the method of Konigsmark (1970).

Cell size was determined by camera lucida tracings of the somata, nuclei, and nucleoli of at least $20 \mathrm{SNB}$ and RDLN motoneurons of each animal. Sections chosen for tracing were spaced equally throughout the rostrocaudal extent of each nucleus, and all possible SNB and RDLN motoneurons were traced from each selected section to avoid experimenter bias. The mean sizes of SNB and RDLN motoneurons were calculated for each animal, and this value was used in statistical analysis.

Data analysis. Effects of treatments on motoneuron number and size were evaluated using one-way ANOVA. Post hoc, pairwise comparisons were performed using the Bonferroni correction for multiple comparisons. Means \pm SEM are given throughout, and $p$ values $<0.05$ are considered significant.

\section{RESULTS \\ Perineal injections of trkB-IgG, trkC-IgG, and AADH- CNTF attenuate the androgenic sparing of SNB motoneurons}

We asked first whether the rescue of SNB motoneurons could be blocked by localized, perineal injections of trophic factor antagonists. The anatomy of the SNB neuromuscular system and the design of the study are illustrated in Figure 1. Evidence suggests that by the day of birth, male rat pups have already been exposed to enough androgens to permanently rescue the SNB system (Breedlove and Arnold, 1983). We therefore took the approach of androgenizing newborn females, and simultaneously applying a blockade of trophic factor receptors.

Signaling through CNTF receptors was blocked using AADHCNTF (Di Marco et al., 1996), and trk-IgGs were used to bind and sequester endogenously produced neurotrophins. Seven experimental groups were initially compared: oil-treated control females receiving perineal injections of PBS (oil/PBS) and TPtreated females receiving either PBS, IgG alone $(2.5 \mu \mathrm{g})$, trkA$\operatorname{IgG}(2.5 \mu \mathrm{g})$, trkB-IgG $(2.5 \mu \mathrm{g})$, trkC-IgG $(2.5 \mu \mathrm{g})$, or AADHCNTF $(1 \mu \mathrm{g})$ at the perineum.

There was a significant effect of treatment on SNB motoneuron number $\left(F_{(6,61)}=14.5 ; p<0.0001\right)$ (Fig. 2$)$. As expected, androgenized females had many more SNB motoneurons than did oil-treated females ( $p<0.0005$; TP/PBS vs oil/PBS groups). TrkB-IgG, trkC-IgG, and AADH-CNTF, when administered to androgenized females, each significantly reduced SNB motoneuron number relative to that of TP/PBS females ( $p$ values $\leq 0.01$ in each case). In fact, SNB cell counts in androgenized females receiving AADH-CNTF, trkB-IgG, or trkC-IgG did not differ significantly from counts in oil-treated, control females. Neither trkA-IgG nor human IgG alone had an effect on SNB motoneuron survival ( $p$ values $>0.50$ compared with TP/PBS females). Although not shown here, we also examined the effects of higher doses of AADH-CNTF and trkB-IgG on SNB motoneuron survival ( 5 and $25 \mu \mathrm{g} / \mathrm{d}$, respectively). When administered into the perineum, high doses of AADH-CNTF and trkB-IgG again reduced SNB cell number relative to counts in androgenized controls $(p<0.05$ in both cases), but they were no more effective than the lower doses illustrated in Figure 2.

The effects of our treatments on SNB motoneuron cell size are given in Table 1. The sizes of SNB somas and nucleoli were not significantly affected by treatment. There was an overall effect of treatment on the size of SNB nuclei $\left(F_{(6,61)}=2.68 ; p<0.05\right)$, but none of the individual pairwise comparisons reached statistical significance in post hoc tests. We conclude that our treatments influenced SNB cell number, while having little or no effect on motoneuron cell size.

Motoneuron counts also were determined for the RDLN. RDLN motoneurons are located at the same level of the spinal cord as the SNB and innervate intrinsic muscles of the foot. In contrast to effects in the SNB, neither TP nor any of the trophic factor antagonists influenced motoneuron number in the RDLN 


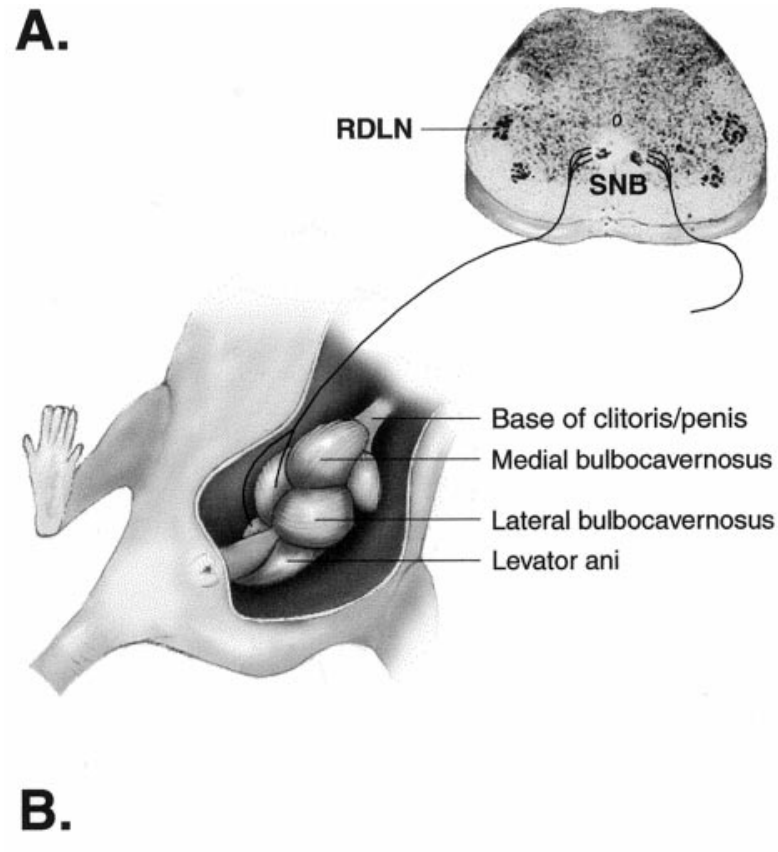

TP or Oil

SubQ, nape of neck

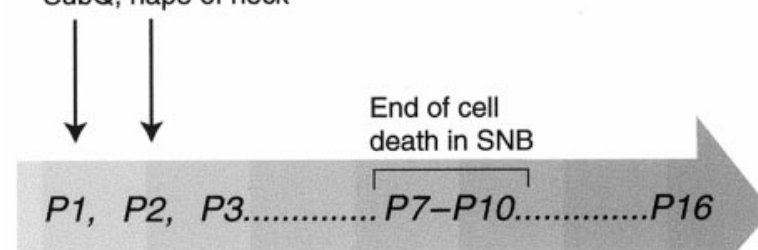

(birth)



Trophic factor antagonists or control solutions, into perineum

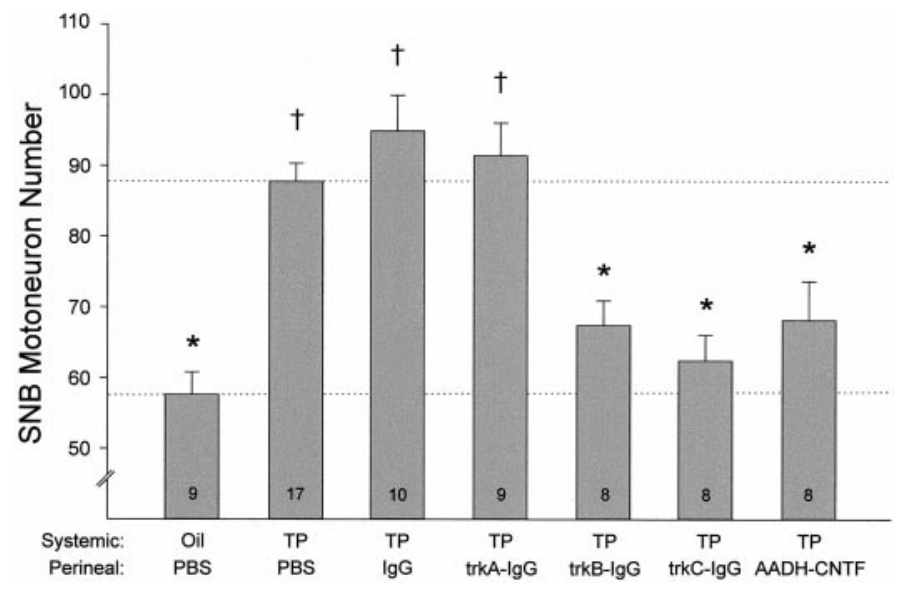

Figure 2. Perineal administration of trophic factor antagonists attenuates the sparing of SNB motoneurons. The number of motoneurons in the SNB of female rats receiving systemic injections of sesame oil or testosterone propionate $(T P)$ and perineal injections of $\mathrm{PBS}, \mathrm{IgG}$ alone $(2.5$ $\mu \mathrm{g}$ ), trk-IgGs (each at $2.5 \mu \mathrm{g}$ ), or AADH-CNTF (1 $\mu \mathrm{g})$. TrkB-IgG, trkC-IgG, and AADH-CNTF each significantly reduced the androgenic sparing of SNB motoneurons. * indicates significantly different from TP/PBS androgenized controls; $\dagger$ indicates significantly different from Oil/PBS controls. Dashed lines indicate the mean number of motoneurons in the SNB of the two control groups (TP/PBS and Oil/PBS). Numbers at the base of each bar indicate sample size.

regulate the androgenic rescue of SNB motoneurons innervating the androgen-dependent BC/LA muscles. Alternatively, it remained possible that the antagonist treatments reduced the survival of androgen-independent SNB motoneurons that survive even in control females and primarily innervate the external anal sphincter muscle. To test this possibility, female rat pups were treated with subcutaneous injections of sesame oil on P1 and P2 and perineal injections of either PBS, trkB-IgG $(2.5 \mu \mathrm{g})$, or trkC-IgG $(2.5 \mu \mathrm{g})$ on P1, P2, and P3. AADH-CNTF was not available for this experiment. As is evident in Figure 3, the trophic factor antagonists did not reduce SNB motoneuron number in oil-treated females $\left(F_{(2,29)}=0.88 ; p>0.40\right)$. It seems likely, therefore, that perineal injections of trophic factor antagonists reduce SNB motoneuron number in androgenized females by blocking the rescue of those motoneurons innervating the androgen-dependent $\mathrm{BC}$ and LA muscles.

Table 1. Cross-sectional areas of the somas, nuclei, and nucleoli of SNB motoneurons on postnatal day 16

\begin{tabular}{|c|c|c|c|}
\hline & \multicolumn{3}{|l|}{ Cell size } \\
\hline & $\begin{array}{l}\text { Somas } \\
\left(\mu \mathrm{m}^{2}\right)\end{array}$ & $\begin{array}{l}\text { Nuclei } \\
\left(\mu \mathrm{m}^{2}\right)\end{array}$ & $\begin{array}{l}\text { Nucleoli } \\
\left(\mu \mathrm{m}^{2}\right)\end{array}$ \\
\hline Oil/PBS & $336 \pm 14$ & $117 \pm 4$ & $7.5 \pm 0.2$ \\
\hline $\mathrm{TP} / \mathrm{PBS}$ & $359 \pm 8$ & $128 \pm 3$ & $7.9 \pm 0.2$ \\
\hline TP/AADH-CNTF & $345 \pm 8$ & $124 \pm 4$ & $7.8 \pm 0.2$ \\
\hline TP/trkA-IgG & $344 \pm 9$ & $126 \pm 4$ & $7.9 \pm 0.2$ \\
\hline TP/trkB-IgG & $334 \pm 10$ & $129 \pm 3$ & $7.8 \pm 0.3$ \\
\hline $\mathrm{TP} /$ trkC-IgG & $370 \pm 21$ & $132 \pm 6$ & $8.4 \pm 0.4$ \\
\hline $\mathrm{TP} / \mathrm{IgG}$ & $330 \pm 13$ & $115 \pm 4$ & $7.9 \pm 0.3$ \\
\hline One-way ANOVA & n.s. & $p=0.023$ & n.s. \\
\hline
\end{tabular}

Values are mean \pm SEM; n.s., not significant $(p>0.05)$.
$\left(F_{(6,54)}=1.30 ; p>0.25\right.$; data not shown). Body weights at time of killing also did not differ across groups $\left(F_{(6,67)}=1.01 ; p>0.40\right.$; data not shown). Thus, the reductions in SNB motoneuron number after treatment with trkB-IgG, trkC-IgG, and AADH-CNTF do not appear to be attributable to nonspecific toxic effects on motoneurons or on the health of the animals.

\section{Trophic factor antagonists do not alter SNB motoneuron number in oil-treated females}

The findings described above suggest that endogenously produced trophic factors signaling through $\operatorname{CNTFR} \alpha, \operatorname{trkB}$, and trkC 


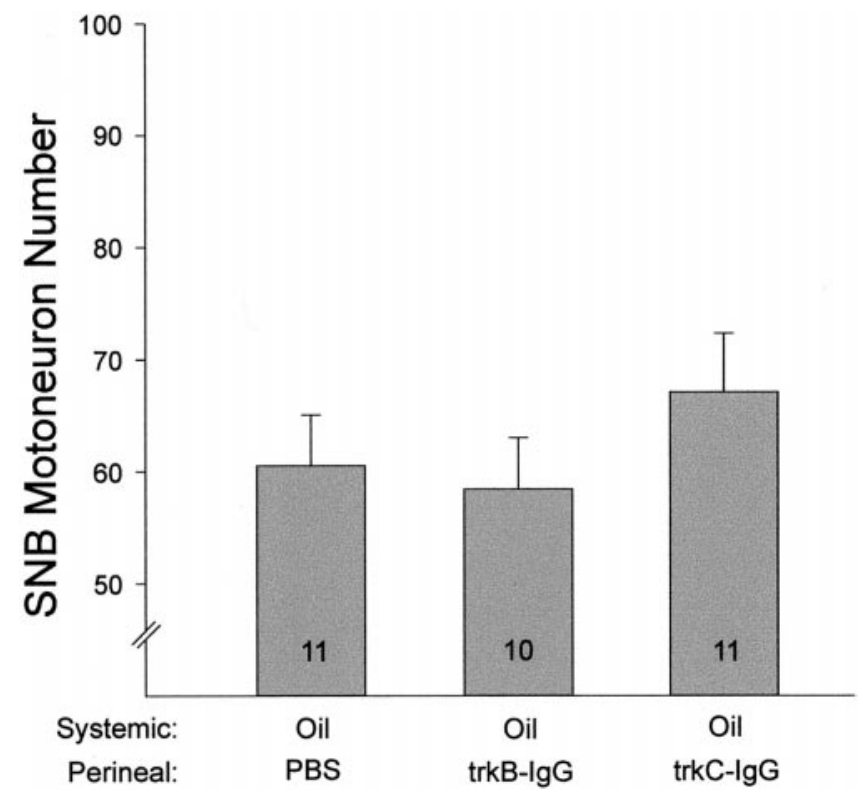

Figure 3. Trk-IgGs do not decrease motoneuron number in oil-treated females. The number of SNB motoneurons in oil-treated females that were given perineal injections of PBS, trkB-IgG $(2.5 \mu \mathrm{g} / \mathrm{d})$, or trkC-IgG $(2.5 \mu \mathrm{g} / \mathrm{d})$ is shown. There were no significant differences between groups. Numbers at the base of each bar indicate sample size.

\section{Trophic factor antagonists do not block masculinization of the SNB when administered systemically}

Next, we asked whether trkB-IgG, trkC-IgG, or AADH-CNTF could block masculinization of SNB motoneuron number when delivered systemically rather than into the perineum. By comparing the efficacy of systemic and perineal injections, we might begin to address questions regarding the site of action of injected antagonists. We reasoned that antagonists injected at any site will spread to some extent throughout the body, but that the perineal muscles and SNB motor nerve terminals should have better access to antagonists delivered perineally than to antagonists delivered systemically.

Two adjustments were made from the previous experiments in an attempt to enhance the efficacy of systemic injections: doses of antagonists were increased 10 - to 20 -fold over those administered perineally, and injections were given twice per day. Newborn female rats were androgenized as above, and antagonists were administered as five subcutaneous injections at the nape of the neck given every $12 \mathrm{hr}$ between P1 and the morning of P3. Then, pups were left undisturbed until killing at P16.

The overall effect of treatment on SNB motoneuron number did not quite reach significance $\left(F_{(3,29)}=2.77 ; p=0.059\right)$ (Fig. $4 A$ ), suggesting that systemic administration of trophic factor antagonists is ineffective or marginally effective in attenuating the androgenic rescue of SNB cells. TrkB-IgG was clearly ineffective when administered systemically (Fig. 4A). There appeared to be a trend for slightly lower SNB cell numbers in animals treated systemically with trkC-IgG or AADH-CNTF; however, if post hoc tests were performed, none of the individual antagonist treatments significantly altered SNB motoneuron number relative to cell counts in androgenized controls (all $p$ values $\geq 0.05$ ). We conclude that systemic administration of trkB-IgG, trkC-IgG, or AADH-CNTF at the doses used here does not block the androgenic sparing of SNB cells.
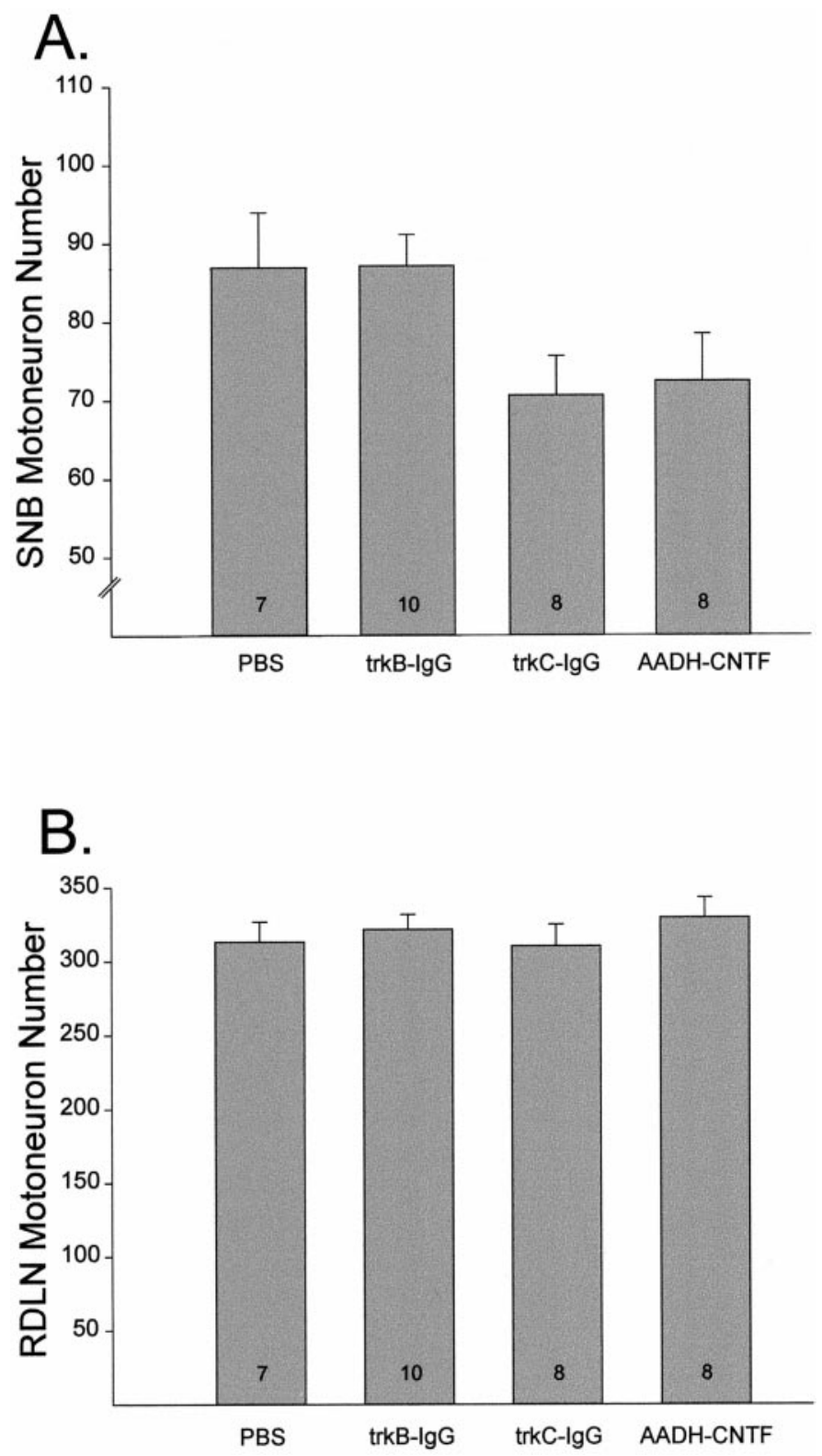

Figure 4. Motoneuron number in animals receiving systemic injections of trophic factor antagonists. The number of SNB $(A)$ and RDLN $(B)$ motoneurons in androgenized female rats treated every $12 \mathrm{hr}$ with subcutaneous injections of PBS, trkB-IgG $(25 \mu \mathrm{g})$, trkC-IgG $(25 \mu \mathrm{g})$, or AADH-CNTF $(5 \mu \mathrm{g})$ is shown. There were no significant differences among the groups for either motor pool. Numbers at the base of each bar indicate sample size.

As was seen after perineal injections, there was no effect of subcutaneous antagonist treatments on RDLN motoneuron number (Fig. $4 B)\left(F_{(3,29)}=0.44 ; p>0.70\right)$. There also was no effect on SNB cell size, RDLN cell size, or body weight (all $p$ values $>$ 0.15 ; data not shown).

\section{DISCUSSION}

SNB motoneuron cell death extends postnatally and is controlled by androgens. In the present study, we took advantage of these features of the SNB system to test the requirement for specific, endogenously produced trophic factors in motoneuron survival. Androgens were administered to newborn female rat pups during a two-day interval to rescue SNB motoneurons from cell death. 
Coincident with the androgen stimulation, trk-IgGs or AADHCNTF was applied to neutralize endogenous trophic factors of the neurotrophin or CNTF families. When injected into the perineum, trkB-IgG, trkC-IgG, and AADH-CNTF each reduced the survival of SNB motoneurons in androgenized females. These findings indicate that trkB ligands (BDNF and/or NT-4/5), trkC ligands (NT-3), and ligands of the CNTF receptor all contribute to the trophic support of SNB motoneurons. TrkAIgG did not alter SNB cell number in androgenized females, suggesting that the trkA ligand, NGF, does not regulate SNB motoneuron survival.

\section{Endogenous trophic factors regulating motoneuron survival}

Trophic factors of the CNTF and neurotrophin families enhance the survival of motoneurons in vitro and in vivo (Elliott and Snider, 1996; Mitsumoto and Tsuzaka, 1999). Despite this, the developmental cell death of motoneurons is not affected in transgenic mice with deletions of the genes for CNTF, NGF, BDNF, NT-3, NT-4/5, trkA, trkB, or trkC (for review, see Elliott and Snider, 1996; Ip and Yancopoulos, 1996). The minimal effects of such knock-out studies generally have been attributed to redundancy and/or compensatory mechanisms that take place when a gene product is eliminated throughout embryonic development. In the current study, trophic factor interactions were normal until perturbed during the first few postnatal days. Under these conditions, signaling through $\operatorname{trkB}, \operatorname{trkC}$, and CNTFR $\alpha$ all appear to be required for the rescue of SNB motoneurons. These findings raise the interesting possibility that the acute deprivation of a single trophic factor may have very different consequences from the chronic absence of that factor or its cognate receptor. This might occur if, for example, previous exposure to endogenous trophic factors alters the trophic "dependencies" of a developing motoneuron, as has been described for sensory neurons in vitro (Vogel and Davies, 1991).

The present results also suggest that SNB motoneuron survival requires the simultaneous activation of at least two classes of receptors that use distinct, as well as overlapping, signal cascades. TrkB and trkC are tyrosine kinase receptors that activate multiple intracellular signaling cascades, including the ras/raf/MAP kinase pathway (Heumann, 1994). In contrast, CNTFR $\alpha$ is part of a three-part cytokine receptor complex that signals primarily through a JAK/STAT pathway (Ip and Yancopoulos, 1996). CNTF and BDNF have been shown previously to have synergistic effects on motoneurons in vitro and in vivo (Wong et al., 1993; Mitsumoto et al., 1994; Stoop and Poo, 1996). However, the molecular basis for the collaborative actions of neural cytokines and neurotrophins remains unknown.

The observation that AADH-CNTF attenuated the rescue of SNB motoneurons is consistent with our previous findings that exogenous CNTF increases SNB cell number in newborn female rats (Forger et al., 1993) and that deletion of the CNTFR $\alpha$ gene eliminates the sex difference in the SNB of mice (Forger et al., 1997). We conclude that an endogenous ligand of CNTFR $\alpha$ is required for motoneuron survival, including SNB motoneuron survival. That ligand is unlikely to be CNTF itself, however, as several lines of evidence indicate that a second ligand of $\mathrm{CNTFR} \alpha$ exists and regulates motoneuron number during development (DeChiara et al., 1995; Shelton, 1996; Forger et al., 1997). Although not yet fully characterized, a molecular heterodimer has been identified recently that may turn out to be the long-sought, second ligand for the CNTF receptor (Elson et al., 2000).

The perineal administration of trkB-IgG or trkC-IgG also decreased SNB motoneuron number in androgenized females. The trkB ligand, BDNF, has been shown previously to regulate androgen receptor immunoreactivity of adult SNB motoneurons (Al-Shamma and Arnold, 1997; Yang and Arnold, 2000); the present results suggest that BDNF (and/or NT-4) is also required for SNB cell survival during development. It is somewhat surprising that trkB-IgG was no more effective than trkC-IgG in reducing motoneuron survival in the present study. The trkC ligand, NT-3, is primarily implicated in the survival of Ia spinal afferents (Ernfors et al., 1994; Klein et al., 1994), and exogenous NT-3 is a less potent trophic factor for $\alpha$ motoneurons than either BDNF or NT-4/5 in several assays (Sendtner et al., 1992; Koliatsos et al., 1993; Houenou et al., 1994; Fernandes et al., 1998; Wiese et al., 1999). However, the present findings, together with the observation that NT-3 is expressed at high levels in developing skeletal muscles (Funakoshi et al., 1995; Griesbeck et al., 1995), suggest that endogenous NT-3 may be a more important motoneuron trophic factor than previously recognized.

The perineal administration of trkA-IgG did not affect SNB motoneuron number at the dose tested here. This indicates that the trkA ligand, NGF, is not involved in the regulation of SNB motoneuron cell death. In the absence of an activity assay for trkA-IgG in vivo, this conclusion must be viewed as tentative. However, the lack of effect of trkA-IgG is consistent with several previous demonstrations that exogenous NGF does not support the survival of either spinal or brainstem motoneurons, in vitro or in vivo (Sendtner et al., 1992; Houenou et al., 1994; Baumgartner and Shine, 1997; Wiese et al., 1999). In this respect, the trophic factor requirements of developing SNB motoneurons appear to be similar to those of other, nonsexually dimorphic motoneurons.

These observations naturally raise the question of how a blockade of endogenous trophic factors would reduce motoneuron survival during cell death in other, nonandrogen-dependent motor pools. Our antagonist treatments did not affect motoneuron number in the RDLN of the lateral horn. Although this observation was useful in confirming that the antagonists are not generally toxic, the perineal injections that effectively reduced SNB cell number were distant from RDLN target muscles, which are primarily located in the foot. In addition, motoneuron cell death in the lateral horn is complete before birth (Harris and McCaig,1984; Oppenheim, 1986), i.e., before the start of our treatments. To test the role of endogenous, target-derived trophic factors in the regulation of developmental cell death for most motoneurons, one would have to impose a trophic factor blockade at the relevant target muscles during embryonic development. This would obviously be technically difficult and may explain why, to the best of our knowledge, no previous study has attempted a similar trophic factor deprivation during the time of cell death for any other mammalian motor system. In embryonic chicks, Krieglstein et al. (2000) have recently reported profound effects on motoneuron cell death after the systemic immunoneutralization of endogenous transforming growth factors $\beta$.

\section{Site(s) of trophic factor action}

Converging evidence indicates that androgens act at the perineal muscles to indirectly spare SNB cells (Fishman et al., 1990; Freeman et al., 1997; Jordan et al., 1997). In the present study, trophic factor antagonists attenuated the androgenic rescue of SNB motoneurons when low doses were injected into the peri- 
neum, whereas much higher doses did not significantly reduce motoneuron number when administered systemically. Although we cannot rule out central sites of action on the basis of these findings, the observations are consistent with the idea that trkBIgG, trkC-IgG, and AADH-CNTF prevented the sparing of SNB cells primarily by blocking trophic factor interactions in the perineum. Specifically, testosterone may act at the BC/LA muscles to prevent their degeneration and to increase the availability of target-derived BDNF, NT-4/5, NT-3, and/or a CNTF-like factor. Although the trophic factors produced by the perineal muscles have not yet been fully characterized, preliminary evidence indicates that NT-3 and NT-4/5 are present in the BC/LA of newborn rats at concentrations similar to those found in hindlimb muscles (J.-J. Park and N. G. Forger, unpublished observations). Other developing skeletal muscles produce BDNF, NT-3, and NT-4/5 (Koliatsos et al., 1993; Funakoshi et al., 1995; Griesbeck et al., 1995). Because developing motoneurons express the corresponding trophic factor receptors (Yan et al., 1992; Henderson et al., 1993; Koliatsos et al., 1993; MacLennan et al., 1996), such target-derived factors could presumably enhance SNB motoneuron survival via a classical, retrograde mechanism.

In addition, because $\mathrm{CNTF}, \mathrm{BDNF}$, and NT-4/5 each regulate synaptic strength in developing Xenopus muscle-motoneuron cocultures (Stoop and Poo, 1996; Wang et al., 1998), changes in synaptic activity could conceivably have contributed to the effects of trophic factor blockade seen here. Finally, the BC/LA muscles themselves express CNTFR $\alpha$ and trkB during perinatal life (Xu and Forger,1998; and our unpublished observations), and exogenous CNTF prevents BC/LA atrophy in newborn females (Forger et al., 1993). Thus, AADH-CNTF and/or trkB-IgG might influence SNB cell survival via an indirect effect on SNB target muscles. Although our preliminary analyses indicate that the trophic factor antagonists used here did not prevent the androgenic rescue of the $\mathrm{BC} / \mathrm{LA}$ muscles, we are currently exploring the possibility of more subtle effects of trophic factor antagonists on muscle development.

\section{REFERENCES}

Al-Shamma HA, Arnold AP (1997) Brain-derived neurotrophic factor regulates expression of androgen receptors in perineal motoneurons. Proc Natl Acad Sci USA 94:1521-1526.

Baumgartner BJ, Shine HD (1997) Targeted transduction of CNS neurons with adenoviral vectors carrying neurotrophic factor genes confers neuroprotection that exceeds the transduced population. J Neurosci 17:6504-6511.

Bengston L, Lopez V, Watamura S, Forger NG (1996) Short- and longterm effects of ciliary neurotrophic factor on androgen-sensitive motoneurons in the lumbar spinal cord. J Neurobiol 31:263-273.

Bennett DLH, Koltzenburg M, Priestley J, Shelton DL, McMahon SB (1998) Endogenous nerve growth factor regulates the sensitivity of nociceptors in the adult rat. Eur J Neurosci 10:1282-1291.

Bothwell M (1995) Functional interactions of neurotrophins and neurotrophin receptors. Annu Rev Neurosci 18:223-253.

Breedlove SM (1986) Cellular analyses of hormone influence on motoneuronal development and function. J Neurobiol 17:157-176.

Breedlove SM, Arnold AP (1983) Hormonal control of a developing neuromuscular system. II. Sensitive periods for the androgen-induced masculinization of the rat spinal nucleus of the bulbocavernosus. J Neurosci 3:424-432.

Cabelli RJ, Shelton DL, Segal RA, Shatz CJ (1997) Blockade of endogenous ligands of trkB inhibits formation of ocular dominance columns. Neuron 19:63-76.

Cihak R, Gutmann E, Hanzlikova V (1970) Involution and hormoneinduced persistence of the muscle sphincter (levator) ani in female rats. J Anat 106:93-110.

DeChiara TM, Vejsada R, Poueymirou WT, Acheson A, Suri C, Conover JC, Friedman B, McClain J, Pan L, Stahl N, Ip NY, Kato A, Yancopoulos GD (1995) Mice lacking the CNTF receptor, unlike mice lacking CNTF, exhibit profound motor neuron deficits at birth. Cell 83:313-322.

Di Marco A, Gloaguen I, Graziani R, Paonessa G, Saggio I, Hudson KR,
Laufer R (1996) Identification of ciliary neurotrophic factor (CNTF) residues essential for leukemia inhibitory factor receptor binding and generation of CNTF receptor antagonists. Proc Natl Acad Sci USA 93:9247-9252.

Elliott JL, Snider WD (1996) Motor neuron growth factors. Neurology 47 [Suppl 2]:S47-S53.

Elson GCA, Lelièvre E, Guillet C, Chevalier S, Plun-Favreau H, Froger J, Suard I, Benoit de Coignac A, Delneste Y, Bonnefoy J-Y, Gauchat J-F, Gascan H (2000) CLF associates with CLC to form a functional heteromeric ligand for the CNTF receptor complex. Nat Neurosci 3:867-872.

Ernfors P, Lee K-F, Kucera J, Jaenisch R (1994) Lack of neurotrophin-3 leads to deficiencies in the peripheral nervous system and loss of limb proprioceptive afferents. Cell 77:503-512.

Fernandes KJL, Kobayashi NR, Jasmin BJ, Tetzlaff W (1998) Acetylcholinesterase gene expression in axotomized rat facial motoneurons is differentially regulated by neurotrophins: correlation with trkB and trkC mRNA levels and isoforms. J Neurosci 18:9936-9947.

Fishman RB, Chism L, Firestone GL, Breedlove SM (1990) Evidence for androgen receptors in sexually dimorphic perineal muscles of neonatal male rats. Absence of androgen accumulation by the perineal motoneurons. J Neurobiol 21:694-704.

Forger NG, Roberts SL, Wong V, Breedlove SM (1993) Ciliary neurotrophic factor maintains motoneurons and their target muscles in developing rats. J Neurosci 13:4720-4726.

Forger NG, Wong V, Breedlove SM (1995) Ciliary neurotrophic factor arrests muscle and motoneuron degeneration in androgen-insensitive rats. J Neurobiol 28:354-362.

Forger NG, Howell ML, Bengston L, MacKenzie L, DeChiara TM, Yancopoulos GD (1997) Sexual dimorphism in the spinal cord is absent in mice lacking the ciliary neurotrophic factor receptor. J Neurosci 17:9605-9612.

Freeman LM, Watson NV, Breedlove SM (1997) Androgen spares androgen-insensitive motoneurons from apoptosis in the spinal nucleus of the bulbocavernosus in rats. Horm Behav 30:424-433.

Funakoshi H, Belluardo N, Arenas E, Yamamoto Y, Casabona A, Persson H, Ibáñez CF (1995) Muscle-derived neurotrophin-4 as an activity-dependent trophic signal for adult motor neurons. Science 268:1495-1499.

Griesbeck O, Parsadanian AS, Sendtner M, Thoenen H (1995) Expression of neurotrophins in skeletal muscle: quantitative comparison and significance for motoneuron survival and maintenance of function. $\mathrm{J}$ Neurosci Res 42:21-33.

Harris AJ, McCaig CD (1984) Motoneuron death and motor unit size during embryonic development of the rat. J Neurosci 4:13-24.

Henderson CE, Camu W, Mettling C, Gouin A, Poulsen K, Karihaloo M, Rullamas J, Evans T, McMahon SB, Armanini MP, Berkmeier L, Phillips HS, Rosenthal A (1993) Neurotrophins promote motor neuron survival and are present in embryonic limb bud. Nature 363:266-270

Heumann R (1994) Neurotrophin signalling. Curr Opin Neurobiol $4: 668-679$

Hollyday M, Hamburger V (1976) Reduction of the naturally occurring motor neuron loss by enlargement of the periphery. J Comp Neurol 170:311-320.

Houenou LJ, Li L, Lo AC, Yan Q, Oppenheim RW (1994) Naturally occurring and axotomy-induced motoneuron death and its prevention by neurotrophic agents: a comparison between chick and mouse. In: Progress in brain research (Van Pelt J, Corner MA, Uylings HBM, Lopes da Silva FH, eds), pp 217-226. New York: Elsevier Science.

Ip NY, Yancopoulos GD (1996) The neurotrophins and CNTF: Two families of collaborative neurotrophic factors. Annu Rev Neurosci 19:491-515.

Jordan CL, Breedlove SM, Arnold AP (1982) Sexual dimorphism and the influence of neonatal androgen in the dorsolateral motor nucleus of the rat lumbar spinal cord. Brain Res 249:309-314.

Jordan CL, Padgett B, Hershey J, Prins G, Arnold A (1997) Ontogeny of androgen receptor immunoreactivity in lumbar motoneurons and in the sexually dimorphic levator ani muscle of male rats. J Comp Neurol 379:88-98.

Klein R, Silos-Santiago I, Smeyne RJ, Lira SA, Brambilla R, Bryant S, Zhang L, Snider WD, Barbacid M (1994) Disruption of the neurotrophin-3 receptor gene trkC eliminates Ia muscle afferents and results in abnormal movements. Nature 368:249-251.

Koliatsos VE, Clatterbuck RE, Winslow JW, Cayouette MH, Price DL (1993) Evidence that brain-derived neurotrophic factor is a trophic factor for motor neurons in vivo. Neuron 10:359-367.

Konigsmark BW (1970) Methods for the counting of neurons. In: Contemporary res methods in neuroanatomy (Nauta WJH, Ebbesson SOE, eds), pp 315-340. New York: Springer.

Krieglstein K, Richter S, Farkas L, Schuster N, Dünker N, Oppenheim RW, Unsicker K (2000) Reduction of endogenous transforming growth factors $\beta$ prevents ontogenetic neuron death. Nat Neurosci 3:1085-1090. 
Lance-Jones C (1982) Motoneuron cell death in the developing lumbar spinal cord of the mouse. Dev Brain Res 4:473-479.

Lowenstein DH, Arsenault L (1996) The effects of growth factors on the survival and differentiation of cultured dentate gyrus neurons. J Neurosci 16:1759-1769.

MacLennan AJ, Vinson EN, Marks L, McLaurin DL, Pfeifer M, Lee N (1996) Immunohistochemical localization of ciliary neurotrophic factor receptor $\alpha$ expression in the rat nervous system. J Neurosci 16:621-630.

MacLennan AJ, Neitzel KL, Devlin BK, Garcia J, Hauptman GA, Gloaguen I, Di Marco A, Laufer R, Lee N (2000) In vivo localization and characterization of functional ciliary neurotrophic factor receptors which utilize JAK-STAT signaling. Neuroscience 99:761-772.

McMahon SB, Bennett DL, Priestley JV, Shelton DL (1995) The biological effects of endogenous nerve growth factor on adult sensory neurons revealed by a trkA-IgG fusion molecule. Nat Med 1:774-780.

Meazza C, Di Marco A, Fruscella P, Gloaguen I, Laufer R, Sironi M, Sipe JD, Villa P, Romano M, Ghezzi P (1997) Centrally mediated inhibition of local inflammation by ciliary neurotrophic factor. Neuroimmunomodulation 4:271-276.

Mitsumoto H, Tsuzaka K (1999) Neurotrophic factors and neuromuscular disease. I. General comments, the neurotrophin family, and neuropoietic cytokines. Muscle Nerve 22:983-999.

Mitsumoto H, Ikeda K, Klinosz B, Cedarbaum JM, Wong V, Lindsay RM (1994) Arrest of motor neuron disease in wobbler mice cotreated with CNTF and BDNF. Science 265:1107-1110.

Nicolopoulos-Stournaras S, Iles JF (1983) Motor neuron columns in the lumbar spinal cord of the rat. J Comp Neurol 217:75-85.

Nordeen EJ, Nordeen KW, Sengelaub DR, Arnold AP (1985) Androgens prevent normally occurring cell death in a sexually dimorphic spinal nucleus. Science 229:671-673.

Oppenheim RW (1986) The absence of significant postnatal motoneuron death in the brachial and lumbar spinal cord of the rat. J Comp Neurol 246:281-286.

Oppenheim RW (1991) Cell death during development of the nervous system. Annu Rev Neurosci 14:453-501.

Oppenheim RW (1996) Neurotrophic survival molecules for motoneurons: an embarrassment of riches. Neuron 17:195-197.
Schroder HD (1980) Organization of the motoneurons innervating the pelvic muscles of the male rat. J Comp Neurol 192:567-587.

Sendtner M, Holtmann B, Kolbeck R, Thoenen H, Barde YA (1992) Brain-derived neurotrophic factor prevents the death of motoneurons in newborn rats after nerve section. Nature 360:757-759.

Shelton D (1996) Are there more members of the CNTF-GPA family? Perspect Dev Neurobiol 4:101-107.

Shelton DL, Sutherland J, Gripp J, Camerato T, Armanini MP, Phillips HS, Carroll K, Spencer SD, Levinson AD (1995) Human trks: molecular cloning, tissue distribution, and expression of extracellular domain immunoadhesins. J Neurosci 15:477-491.

Shimada A, Mason CA, Morrison ME (1998) TrkB signaling modulates spine density and morphology independent of dendrite structure in cultured neonatal Purkinje cells. J Neurosci 18:8559-8570.

Stoop R, Poo M-M (1996) Synaptic modulation by neurotrophic factors: differential and synergistic effects of brain-derived neurotrophic factor and ciliary neurotrophic factor. J Neurosci 16:3256-3264.

Vogel KS, Davies AM (1991) The duration of neurotrophic factor independence in early sensory neurons is matched to the time course of target field innervation. Neuron 7:819-830.

Wang X, Berninger B, Poo M-M (1998) Localized synaptic actions of neurotrophin-4. J Neurosci 18:4985-4992.

Wiese S, Metzger F, Holtmann B, Sendtner M (1999) The role of p75NTR in modulating neurotrophin survival effects in developing motoneurons. Eur J Neurosci 11:1668-1676.

Wong V, Arriaga R, Ip NY, Lindsay RM (1993) The neurotrophins BDNF, NT-3 and NT-4/5, but not NGF, up-regulate the cholinergic phenotype of developing motor neurons. Eur J Neurosci 5:466-474.

Xu J, Forger NG (1998) Expression and androgen regulation of the ciliary neurotrophic factor receptor $(\mathrm{CNTFR} \alpha)$ in muscles and spinal cord. J Neurobiol 35:217-225.

Yan Q, Elliott J, Snider WD (1992) Brain-derived neurotrophic factor rescues spinal motor neurons from axotomy-induced cell death. Nature 360:753-755.

Yang LY, Arnold AP (2000) BDNF regulation of androgen receptor expression in axotomized SNB motoneurons of adult male rats. Brain Res 852:127-139. 